\title{
Climate-induced historical drift of reference evapotranspiration in Mymensingh region of Bangladesh
}

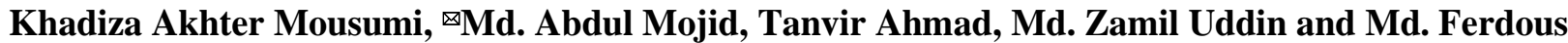 \\ Parvez
}

Department of Irrigation and Water Management, Bangladesh Agricultural University, Mymensingh-2202, Bangladesh

\begin{tabular}{|c|c|}
\hline ARTICLE INFO open ${ }_{\text {Access }}$ & Abstract \\
\hline $\begin{array}{l}\text { Article history: } \\
\text { Received : 22 January } 2019 \\
\text { Accepted : 14 May } 2019 \\
\text { Published: } 30 \text { June } 2019 \\
\end{array}$ & \multirow{3}{*}{$\begin{array}{l}\text { Reference crop evapotranspiration }\left(E T_{\mathrm{o}}\right) \text { is essential for planning and management of irrigation to ensure } \\
\text { optimum utilization of a region's available water resources. } E T_{\mathrm{o}} \text { being an indicator of atmospheric } \\
\text { evaporative demand provides a measure of the integrated effect of climatic parameters like solar radiation, } \\
\text { wind, temperature and humidity. Variation of these climatic parameters over long period of time alters } \\
E T_{\mathrm{o}} \text {. The modified } E T_{\mathrm{o}} \text { is crucial for periodic adjustment of irrigation planning and management. This } \\
\text { study evaluated variation of } E T_{\mathrm{o}} \text { and contribution of the climatic parameters to } E T_{\mathrm{o}} \text {-variation in } \\
\text { Mymensingh region of Bangladesh by analyzing climatic data of } 28 \text { years }(1990-2017) \text {. } E T_{\mathrm{o}} \text { was } \\
\text { determined by FAO Penman-Monteith method and trends of } E T_{\mathrm{o}} \text { and its governing climatic parameters } \\
\text { were evaluated by MAKESENS trend model. The } E T_{\mathrm{o}} \text {-governing climatic parameters revealed contrasting } \\
\text { trends, which also varied in different months of the year. Net radiation and wind speed showed decreasing } \\
\text { trend, while temperature and saturation vapor pressure deficit showed increasing trend. In spite of } \\
\text { contrasting contributions of the climatic parameters, their combined effect reduced } E T_{\mathrm{o}} \text { with a resulting } \\
\text { decreasing trend of the monthly average daily } E T_{\mathrm{o}} \text { over the months of the year except July. These results } \\
\text { enhance our understanding of the effects of climate change on } E T_{\mathrm{o}} \text { and can help correct-planning of water } \\
\text { resources for irrigated agriculture. }\end{array}$} \\
\hline $\begin{array}{l}\text { Keywords: } \\
\text { Climate change, evaporative } \\
\text { demand, trend }\end{array}$ & \\
\hline $\begin{array}{l}\text { Correspondence: } \\
\text { Md. Abdul Mojid } \\
\text { \: ma_mojid@bau.edu.bd }\end{array}$ & \\
\hline
\end{tabular}

Copyright:

(c) (i)

(92019 by authors and BAURES. This work is licensed under the Creative Commons Attribution International License (CC By 4.0).

\section{Introduction}

Evapotranspiration is a vital dynamic component of hydrological cycle. Reference crop evapotranspiration $\left(E T_{\mathrm{o}}\right)$ is a standard for evapotranspiration, which regulates growth and development of crops. $E T_{\mathrm{o}}$ is required in many hydrological analyses for a region, such as for calculating crop-water demand, scheduling irrigation system, preparing input data to hydrological water-balance models, regional water resources assessment, and planning and management of water resources (Xu et al., 2006). A number of climatic parameters: temperature, relative humidity, wind speed, solar radiation and sunshine duration govern $E T_{\mathrm{o}}$. Climate variability and climate change are now considered to noticeably affect agriculture globally (Adamgbe and Ujoh, 2013), and the situation is expected to worsen in the future (Ochieng et al., 2016). Several regional and local studies, based on observational data sets, have found a variety of results in different regions of the world. In some areas (e.g., Australia), there has been large spatial variability in the evolution of $E T_{\mathrm{o}}$ during the recent decades (Donohue et al., 2010). A declining trend in $E T_{\mathrm{o}}$ was reported for Dhaka and Mymensingh regions in Bangladesh (Karim et al., 2008), north-west hydrological regions of Bangladesh (Rannu et al., 2013; Kader et al., 2014; Mojid et al.,
2015), USA (Irmak et al., 2012) and several regions in China (Ma et al., 2012; Huo et al., 2013; Zhao et al., 2014). Contrasting result was also reported for southern Spain (Espadafor et al., 2011), Greece (Papaioaunou et al., 2011), central Italy (Vergni and Todisco, 2011), Romania (Platineau et al., 2012), Florida (Abtew et al., 2011), central India (Darshana et al., 2012) and Iran (Kousari and Ahani, 2012; Tabari et al., 2012). The dominant cause of increasing $E T_{\mathrm{o}}$ was increased temperature in the Yellow River basin of China (Liu et al., 2010) and Romania (Paltineanu et al., 2012) but increased net radiation in Greece (Papaioaunou et al., 2011). These observations imply that climate change impacts are region-specific. Both under decreasing and increasing $E T_{0}$, crop-water demand must be adjusted periodically for developing appropriate irrigation scheduling systems. So, the changes in $E T_{\mathrm{o}}$ due to climate change is of great significance in water resource planning for irrigation management and updating climate-change impacts over time.

Bangladesh is regarded as one of the most vulnerable countries in the world to climate change (Pouliotte et al., 2009; Huq and Rabbani, 2011). Although quite extensive investigations on climate variability and change and their impacts on agriculture and water resources were done so far in many countries, such 
researches still remain inadequate in Bangladesh. Moreover, the limited studies done so far often do not provide detailed information for all regions of the country. For example, the trend of reference crop evapotranspiration, $E T_{\mathrm{o}}$, and the degree of contribution of the climatic parameters to $E T_{\mathrm{o}}$ have not been investigated in detail for all regions, especially in the north-central Hydrological Region in which Mymensingh is located. Also, continuous evaluation of this information with up-to-date climatic data is needed to understand how climate change would affect future $E T_{\mathrm{o}}$. So, this study aimed (i) to detect and estimate trend of $E T_{\text {o }}$ over the years from 1990 to 2017 and (ii) to identify contribution of the climatic parameters in the variation of $E T_{\mathrm{o}}$ for Mymensingh region.

\section{Methodology}

\section{Data collection}

Bangladesh has been divided into seven Hydrological Regions considering surface water flow processes and major rivers as boundaries. The north-central hydrological region (Fig. 1) comprises 11 administrative districts of which Dhaka, Mymensingh and Tangail have weather stations for recording climatic data. The weather station of Mymensingh (24 $38^{\prime} 3^{\prime \prime}$ north latitude and 90 $16^{\prime} 4^{\prime \prime}$ east longitude), called Agro-Meteorology cum Pilot Balloon Observatory Station, is located at Bangladesh Agricultural University (BAU) Research Farm. Weather data, recorded at this station, is preserved both at the Bangladesh Meteorological Department in Dhaka and BAU. This study analyzed climatic data of Mymensingh weather station. The daily climatic parameters: maximum and minimum air temperature, dew point temperature, maximum and minimum relative humidity, rainfall, wind speed, sunshine duration and solar radiation for a period of 28 years (1990-2017) were collected from BAU.

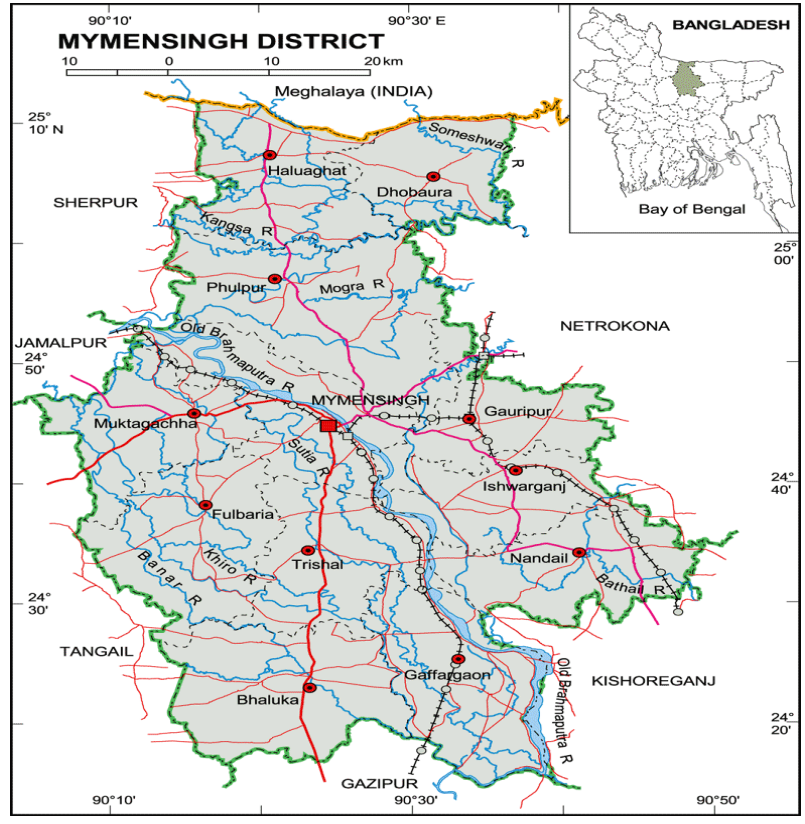

Fig. 1. Map of Mymensingh district Determination of reference crop evapotranspiration Daily reference crop evapotranspiration, $E T_{\mathrm{o}}$, was computed from the daily climatic parameters by using FAO Penman-Monteith method as given by Allen et al. (1998),

$E T_{0}=\frac{0.408 \Delta\left(R_{n}-G\right)+\gamma\left[\frac{900}{T+273} u_{2}\left(e_{s}-e_{a}\right)\right]}{\Delta+\gamma\left(1+0.34 u_{2}\right)}$

In Eq. $1, R_{n}$ is net radiation at crop surface $\left(M J \mathrm{~m}^{-2}\right.$ day $^{-1}$ ), $\mathrm{T}$ is mean daily air temperature ( $\mathrm{C}$ ) at $2 \mathrm{~m}$ height, $\mathrm{u}_{2}$ is wind speed $\left(\mathrm{ms}^{-1}\right)$ at $2 \mathrm{~m}$ height, $\Delta$ is slope of vapor pressure curve $(\mathrm{kPa} / \mathrm{C}), \mathrm{g}$ is soil heat flux density (MJ m ${ }^{-2}$ day $\left.^{-1}\right), \gamma$ is psychrometric constant $\left(\mathrm{kPa} / \mathrm{C}^{-1}\right), \mathrm{e}_{\mathrm{s}}$ is saturation vapor pressures $(\mathrm{kPa})$ and $\mathrm{e}_{\mathrm{a}}$ is actual vapor pressures $(\mathrm{kPa})$. The net radiation at crop surface was calculated at $R_{n}=\left(R_{n s}-R_{n l}\right)$ in which $R_{n s}$ is incoming net short-wave radiation and $R_{n l}$ is outgoing net long-wave radiation, both expressed in $\mathrm{MJ} \mathrm{m}^{-2}$ day $^{-1}$. $\mathrm{R}_{\mathrm{ns}}$ was calculated as $\mathrm{R}_{\mathrm{ns}}=(1-\alpha) \mathrm{R}_{\mathrm{s}} ; \alpha$ is albedo of the surface $(\approx 0.23)$ and $\mathrm{R}_{\mathrm{s}}$ is incoming solar radiation $\left(\mathrm{MJ} \mathrm{m}^{-2}\right.$ day $\left.^{-1}\right) . \mathrm{R}_{\mathrm{s}}$ was calculated from $\mathrm{R}_{\mathrm{s}}=\left(\mathrm{a}_{\mathrm{s}}+\mathrm{b}_{\mathrm{s}} \mathrm{n} / \mathrm{N}\right) \mathrm{R}_{\mathrm{a}}$ in which $\mathrm{n}$ is actual duration of sunshine per daylight $(\mathrm{h})$ and $\mathrm{N}$ is maximum possible duration of sunshine (h) so that $n / N$ is relative sunshine duration, $R_{a}$ is extraterrestrial radiation $\left(\mathrm{MJ} \mathrm{m} \mathrm{m}^{-2} \mathrm{day}^{-1}\right), \mathrm{a}_{\mathrm{s}}$ is a regression constant that expresses fraction of extraterrestrial radiation reaching the earth in overcast days $(n=0)$, and $b_{s}$ is a fraction of extraterrestrial radiation reaching the earth in clear days $(n=N)$. The extraterrestrial radition, $R_{a}$, for each day of the year was calculated by

$\mathrm{R}_{\mathrm{a}}=24(60 / \pi) \mathrm{G}_{\mathrm{sc}} \mathrm{dr}\left[\omega_{\mathrm{s}} \sin (\phi) \sin (\delta)+\cos (\phi) \cos (\delta) \sin \left(\omega_{\mathrm{s}}\right)\right]$

In Eq. $2, \mathrm{G}_{\mathrm{sc}}$ is solar constant $\left(0.0820, \mathrm{MJ} \mathrm{m}^{-2} \mathrm{day}^{-1}\right), \mathrm{d}_{\mathrm{r}}$ is inverse relative distance of Earth-Sun $(\mathrm{m}), \omega_{s}$ is sunset hour angle $(\mathrm{rad}), \varphi$ is latitude ( $\mathrm{rad})$ and $\delta$ is solar declination (rad); $\varphi$ is positive for northern hemisphere and negative for southern hemisphere. The inverse relative distance of Earth-Sun was calculated as $d_{r}=$ $[1+0.033 \cos (2 \pi \mathrm{J} / 365)]$ and the solar declination was calculated as $\delta=[0.409 \sin (2 \pi \mathrm{J} / 365-1.39)]$ where $\mathrm{J}$ is the number of day in a year that varies between 1 (1 January) and 365 or 366 (31 December). J was expressed as $\mathrm{J}=$ [INTEGER $(275 \mathrm{M} / 9-30+\mathrm{D})-2]$ in which $\mathrm{D}$ indicates each day of month $\mathrm{M}$. If $\mathrm{M}<3$ then $\mathrm{J}$ $=\mathrm{J}+2$ and, for leap year and $\mathrm{M}>2, \mathrm{~J}=\mathrm{J}+1$. The sunset hour angle was calculated by $\omega_{\mathrm{s}}=\mathrm{a}_{\mathrm{r}} \cos [\tan (\varphi) \tan (\delta)]$ and the day light hour was expressed by $N=24 / \pi \omega_{\mathrm{s}}$. The outgoing net long-wave radiation, $\mathrm{R}_{\mathrm{nl}}$, was calculated by

$$
R_{n l}=\sigma\left[\frac{T_{\max k}+T_{\min k}}{2}\right]\left(0.34-0.14 \sqrt{e_{a}} \times\left[1.35\left(\frac{R_{s}}{R_{s o}}\right)-0.35\right]\right.
$$

In Eq. 3, $\sigma$ is Stefan-Boltzmann constant $\left(4.903 \times 10^{-9}\right.$ MJ $\mathrm{K}^{-4} \mathrm{~m}^{-2}$ day $\left.^{-1}\right), \mathrm{T}_{\operatorname{maxk}}$ is maximum absolute 
temperature during $24-\mathrm{h}$ period $\left(=\mathrm{T}_{\max }+273.16\right.$; $\mathrm{T}_{\max }$ is daily maximum temperature, ${ }^{\circ} \mathrm{C}$ ), $\mathrm{T}_{\text {mink }}$ is minimum absolute temperature during $24-\mathrm{h}$ period $\left(=\mathrm{T}_{\min }+\right.$ 273.16; $\mathrm{T}_{\min }$ is daily minimum temperature, ${ }^{\circ} \mathrm{C}$ ), $\mathrm{e}_{\mathrm{a}}$ is actual vapor pressure $(\mathrm{kPa})$ and $\mathrm{R}_{\mathrm{s}} / \mathrm{R}_{\mathrm{so}}$ is relative shortwave radiation (limited to $\leq 1.0$ ). $R_{\text {so }}$ is clear sky shortwave radiation $\left(\mathrm{MJ} \mathrm{m}^{-2}\right.$ day $^{-1}$ ) that was calculated by $R_{\text {so }}$ $=\left(0.75+2 \times 10^{-5} \mathrm{z}\right) \mathrm{R}_{\mathrm{a}}$ in which $\mathrm{z}$ is elevation of the weather station $(\mathrm{m})$. The saturation vapor pressure deficit for a period was calculated by the difference between saturation vapor pressure $\left(\mathrm{e}_{\mathrm{s}}\right)$ and actual vapor pressure, $\mathrm{e}_{\mathrm{a}}$. The actual vapor pressure was calculated by

$$
e_{a}=\frac{1}{2\left[\frac{e^{0}\left(T_{\min }\right) R H_{\max }}{100}+\frac{e^{0}\left(T_{\max }\right) R H_{\min }}{100}\right]}
$$

In Eq.4, $\mathrm{e}^{\mathrm{o}}\left(T_{\min }\right)$ is saturation vapor pressure $(\mathrm{kPa})$ at daily minimum temperature and expressed by $\mathrm{e}^{\mathrm{o}}\left(T_{\min }\right)=$ $0.6108 \exp \left\{17.27 T_{\min } /\left(T_{\min }+237.3\right)\right\}$ and $\mathrm{e}^{\mathrm{o}}\left(T_{\max }\right)$ is saturation vapor pressure $(\mathrm{kPa})$ at daily maximum temperature and expressed by $\mathrm{e}^{\mathrm{o}}\left(T_{\max }\right)=0.6108$ $\exp \left\{17.27 T_{\max } /\left(T_{\max }+237.3\right)\right\} . R H_{\min }$ and $R H_{\max }$ are the minimum and maximum relative humidity (\%), respectively. The saturation vapor pressure for a period was calculated by the mean of saturation vapor pressures at mean daily maximum and minimum air temperatures as $e_{\mathrm{s}}=1 / 2\left\{\mathrm{e}^{\mathrm{o}}\left(T_{\max }\right)+\mathrm{e}^{\mathrm{o}}\left(T_{\min }\right)\right\}$. The slope of saturation vapor pressure curve, $\Delta\left(\mathrm{kPa}^{\circ} \mathrm{C}^{-1}\right)$ at mean air temperature, $\mathrm{T}(\mathrm{C})$, was calculated by

$$
\Delta=1 /(T+237.3)^{2}[4098\{0.6108 \exp (17.27 T(T+237.3))\}]
$$

The psychrometric constant, $\gamma\left(\mathrm{kPa}^{\circ} \mathrm{C}^{-1}\right)$, was calculated by $\gamma=\mathrm{C}_{\mathrm{p}} \mathrm{P} / \varepsilon \lambda$ or $0.665 \times 10^{-3} \mathrm{P}$ where $\mathrm{P}$ is atomospheric pressure $(\mathrm{kPa}), \mathrm{C}_{\mathrm{p}}$ is specific heat at constant pressure $\left(1.013 \times 10^{-3},<\mathrm{KJ} \mathrm{kg}^{-1}{ }^{\circ} \mathrm{C}^{-1}\right), \varepsilon$ is the ratio of molecular weight of water vapor to dry air $(0.622)$ and $\lambda$ is latent heat of vaporization (MJ kg ${ }^{-1}$ ). The atmospheric pressure, $\mathrm{P}(\mathrm{kPa})$, was calculated by

$$
P=101.3[(293-0.0065 z) / 293]^{5.26}
$$

where $\mathrm{z}$ is elevation above mean sea level $(\mathrm{m})$. The latent heat of vaporization, $\lambda\left(\mathrm{MJ} \mathrm{kg}^{-1}\right)$ in Equation 1 was calculated by $\lambda=2.501-\left(2.361 \times 10^{-3}\right) \mathrm{T}$. Wind speed at $2 \mathrm{~m}$ above ground surface, $\mathrm{u}_{2}\left(\mathrm{~ms}^{-1} 1\right.$; Eq. 1), was estimated by $\mathrm{u}_{2}=4.87 \mathrm{u}_{\mathrm{z}} / \ln (67.8 \mathrm{z}-5.42)$. The soil heat flux density, $\mathrm{G}_{\text {month,i }}\left(\mathrm{MJ} \mathrm{m}^{-2}\right.$ day $^{-1}$; Eq.1), was calculated by $\mathrm{G}_{\text {month,i }}=0.14\left(\mathrm{~T}_{\text {month,i }}-\mathrm{T}_{\text {month,i-1 }}\right)$ where $\mathrm{T}_{\text {month,i }}$ is mean air temperature ( $\mathrm{C}$ ) of month $\mathrm{i}$ and $\mathrm{T}_{\text {month,i-1 }}$ is mean air temperature $(\mathrm{C})$ of the previous month.

\section{Trend analysis of $E T_{0}$ and $E T_{0}$-governing factors}

The monthly average of daily $E T_{\mathrm{o}}$ and pertinent daily climatic parameters: net radiation, average temperature, saturation vapor pressure deficit and wind speed were determined for each of the study years (1990-2017). The trends of $E T_{\mathrm{o}}$ and climatic parameters were detected and estimated by MAKESENS trend model. This model utilized Mann-Kendall test (Mann, 1945; Kendall, 1975), which is a non-parametric method developed for analyzing trend in time series. The MAKESENS is a software package developed in Microsoft Excel97 and the macros were coded with Microsoft Visual Basic (Salmi et al., 2002). The $E T_{\mathrm{o}}$ and its governing climatic parameters were tested for the presence of any monotonic increasing or decreasing trend with the Mann-Kendall test and then slope of the linear trend, if present, was estimated with non-parametric method of Sen as explained by Gilbert (1987).

\section{Estimation of climatic parameters' contribution to $E T_{0}$}

Step-wise multiple linear regression analysis was done for $E T_{\mathrm{o}}$-governing climatic parameters to evaluate their relative contribution to $E T_{\mathrm{o}}$. This analysis was done following Draper and Smith (2014) and the significant impact-generating parameters were identified. In this technique, one additional climatic variable was added to the regression equation in the consecutive regression analysis. The coefficient of determination $\left(r^{2}\right)$ in each step of regression analysis revealed relative contribution of the climatic parameters (s) in generating $E T_{\mathrm{o}}$. The probability values ( $\mathrm{p}$-values) obtained in the regression analyses provided the significance level at $\mathrm{p} \leq 0.10$, $0.05,0.01$ and 0.001 ; in this study, these probability values were categorized as $\mathrm{p} \leq 0.10$ : fairly significant, $\mathrm{p}$ $\leq 0.05$ : significant, $\mathrm{p} \leq 0.01$ : highly significant and $\mathrm{p} \leq$ 0.001 : very highly significant.

\section{Results and Discussion}

\section{Trend of climatic parameters and $E T_{0}$}

The monthly average of daily net radiation, $R_{\mathrm{n}}$, decreased over the study years (1990-2017) except in the month of October (Table 1). The yearly rate of decrease in $R_{\mathrm{n}}$ was highly significant $(\mathrm{p} \leq 0.01)$ in December and January and fairly significant/ considerable $(p \leq 0.1)$ in May and November. The monthly average of daily air temperature revealed increasing trend except in November and December (Table 1); the increasing rate was significant $(\mathrm{p} \leq 0.05)$ in June, July, August and September but fairly significant in February and October $(p \leq 0.1)$. It seems contrasting that the air temperature increased in most of the months in spite of decreasing net radiation. This might be due to, as Trenberth and Fasullo (2009) reported, that there is an increase in absorption of net radiation in the top of the atmosphere, and from the standpoint of energy budget, the main warming occurs for the increase in absorbed solar radiation that stems directly from decreasing amount of cloud cover. Also, because of poor correlation between net radiation and air temperature, Weller and Wendler (1990) reported that net radiation cannot be used solely as a good indicator of air temperature, especially in summer, when the available heat energy is mostly used up in evaporating water and not to heat the air and therefore raise the 
temperature. Saturation vapor pressure deficit also showed increasing trend except in January, March, April and December, with significant $(p \leq 0.05)$ increasing rate in June and July. It showed significant decreasing rate in December only. Wind speed decreased highly significantly ( $\mathrm{p} \leq 0.001)$ in all the months of the year.

The monthly average of daily reference crop evapotranspiration, $E T_{\mathrm{o}}$, decreased over the study years (1990-2017) except in the month of July (Fig. 2a \& b).

Table 1. Rate of change of net radiation, $R_{n}\left(M J ~ m^{-2} \operatorname{day}^{-1} \operatorname{year}^{-1}\right)$, average air temperature, $T\left({ }^{0} \mathrm{C} \mathrm{year}{ }^{-1}\right)$, saturation vapor pressure deficit, $\left(\mathrm{e}_{\mathrm{s}}-\mathrm{e}_{\mathrm{a}}\right)\left(\mathrm{kPa}_{\mathrm{year}}{ }^{-1}\right)$, wind speed, $\mathrm{u}_{2}\left(\mathrm{~ms}^{-1}\right.$ year $\left.^{-1}\right)$ and monthly average daily reference crop evapotranspiration, $\mathbf{E T}_{0}\left(\mathrm{~mm} \mathrm{day}^{-1}\right.$ year $\left.^{-1}\right)$, in different months of the year (positive values indicate increasing rates and negative values indicate decreasing rates)

\begin{tabular}{|c|c|c|c|c|c|}
\hline \multirow[t]{2}{*}{ Month } & \multicolumn{5}{|c|}{ Rate of change of } \\
\hline & $R_{\mathrm{n}}$ & $T$ & $\left(e_{\mathrm{s}}-e_{\mathrm{a}}\right)$ & $u_{2}$ & $E T_{\mathrm{o}}$ \\
\hline January & $-0.040 * * *$ & 0.005 & -0.003 & $-0.030 * * *$ & $-0.057 * * *$ \\
\hline February & -0.030 & $0.039+$ & 0.002 & $-0.046 * * *$ & $-0.047 * * *$ \\
\hline March & -0.004 & 0.011 & $-0.007+$ & $-0.052 * * *$ & $-0.086 * * *$ \\
\hline April & -0.020 & 0.019 & -0.008 & $-0.063 * * *$ & $-0.067 * * *$ \\
\hline May & $-0.050+$ & 0.022 & 0.001 & $-0.057 * * *$ & $-0.025+$ \\
\hline June & -0.002 & $0.032 *$ & $0.005^{*}$ & $-0.069 * * *$ & -0.002 \\
\hline July & -0.006 & $0.033 * *$ & $0.006 * *$ & $-0.062 * * *$ & 0.007 \\
\hline August & -0.030 & $0.022 *$ & 0.002 & $-0.062 * * *$ & -0.016 \\
\hline September & -0.006 & $0.036 * *$ & 0.003 & $-0.061 * * *$ & -0.018 \\
\hline October & 0.003 & $0.030+$ & 0.002 & $-0.041 * * *$ & $-0.019+$ \\
\hline November & $-0.020+$ & -0.018 & 0.001 & $-0.034 * * *$ & $-0.046 * * *$ \\
\hline December & $-0.030 * *$ & -0.005 & $-0.007 *$ & $-0.029 * * *$ & $-0.053 * * *$ \\
\hline
\end{tabular}

,$+ * * *$ and $* * *$ signs indicate significant at $0.10,0.05,0.01$ and 0.001 level of significance, respectively.
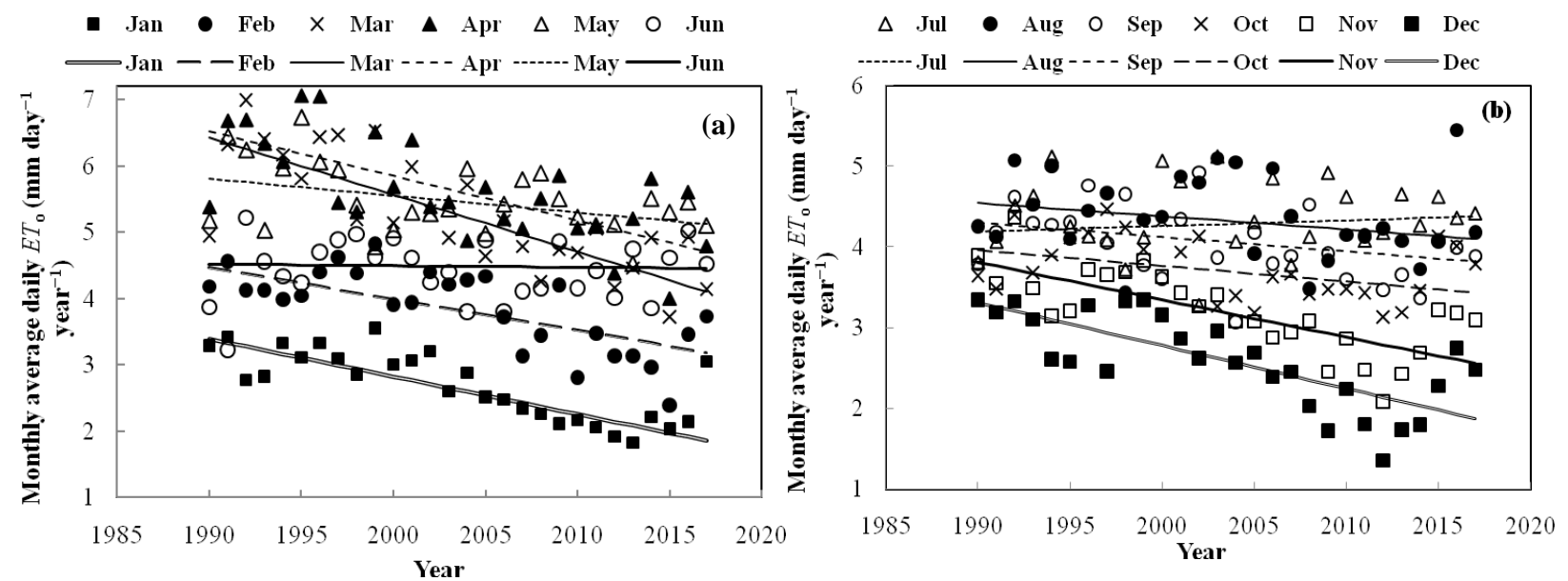

Fig. 2. Monthly average daily reference crop evapotranspiration, $E T_{\mathrm{o}}\left(\mathrm{mm} \mathrm{day}^{-1}\right.$ year $^{-1}$ ), over the study period (1990-2017) for the months of: (a) January to June and (b) July to December.

Contribution of climatic parameters to $E T_{0}$

The coefficient of determination, $r^{2}$ (Table 2), obtained by regressing $E T_{\mathrm{o}}$ against the governing climatic parameters individually, reveals that net radiation, saturation vapor pressure deficit and wind speed controlled $61 \%, 38 \%$ and $70 \%$ of the variation in $E T_{\mathrm{o}}$ in January. The contribution of temperature in the variation of $E T_{\mathrm{o}}$ was only $7 \%$ in this month. Above $60 \%$ of the variation in $E T_{\mathrm{o}}$ was explained by $R_{\mathrm{n}}$ in June, July, August, September and December. The p-values in Table 2 reveal that net radiation put very highly significant $(\mathrm{p} \leq 0.001)$ control on $E T_{\mathrm{o}}$ in January, February, May, June, July, August, September and December. Air temperature, $T$, contributed significantly ( $\mathrm{p} \leq 0.05)$ only in July. The impact of vapor pressure deficit, $\left(e_{\mathrm{s}}-e_{\mathrm{a}}\right)$, in $E T_{\mathrm{o}}$ was significant except in February and November. Wind speed, $u_{2}$, exerted significant control on $E T_{\mathrm{o}}$ in January, February, March, November and December. Individually, net radiation contributed significantly except in April and November and wind speed contributed significantly in January, February, March, November and December. But, wind speed and 
net radiation together controlled $41-92 \%$ of the variation in $E T_{\mathrm{o}}$ in different months of the year (Table 3 ). The combined effect of wind speed and saturation vapor pressure deficit controlled $84-96 \%$ variation in $E T_{\text {o }}$ except in November when it explained only $48 \%$ variation in $E T_{\mathrm{o}}$. Individually, both the wind speed and saturation vapor pressure deficit highly significantly contributed to $E T_{\mathrm{o}}$, with only exception in November when saturation vapor pressure contributed insignificantly (Table 3). Temperature and wind speed conjointly controlled $43-80 \%$ variation in $E T_{\mathrm{o}}$; wind speed exerted insignificant impact in May, October and November and temperature exerted insignificant impact in January, February, March, October, November and December (Table 3). Saturation vapor pressure deficit and net radiation together explained $17-91 \%$ variation in $E T_{\text {o }}$ (Table 4); their contribution was $17 \%$ in November and $91 \%$ in July. The net radiation alone contributed significantly in the variation of $E T_{\mathrm{o}}$ in January, February, April, June, July and August, while the saturation vapor pressure deficit put such contribution only in March, May, June, July and August. Temperature and net radiation together controlled 17 $79 \%$ variation in $E T_{0}$. However, in this combination, net radiation contributed significantly in the variation of $E T_{\mathrm{o}}$ in January, February, May, June, July, August, September and December, but temperature did not contribute significantly. The combined contribution of saturation vapor pressure deficit and temperature varied widely over the months; it explained $12-78 \%$ variation in $E T_{\text {o }}$ (Table 4). The saturation vapor pressure deficit contributed significantly during March to September, but contribution of temperature was always trivial.

Wind speed, net radiation and temperature conjointly controlled 53-93\% of the variation in $E T_{\mathrm{o}}$ (Table 5) in different months during the study period. Wind speed contributed significantly $(\mathrm{p} \leq 0.05)$ in this variation except in April, June, July and November. The contribution of net radiation was significant except in April, July and November, while temperature contributed significantly in May, July, August, September and October. Wind speed, net radiation and saturation vapor pressure deficit controlled $47-99 \%$ of the variation in $E T_{\mathrm{o}}$. Individually, the wind speed, net radiation and saturation vapor pressure deficit contributed highly significantly $(\mathrm{p} \leq 0.001)$ to $E T_{\mathrm{o}}$, with exception in February for wind speed; in February, March and November for radiation and in February and November for saturation vapor pressure deficit. The interaction effects of net radiation, temperature and saturation vapor pressure deficit to the variation of $E T_{\mathrm{o}}$ varied from 30-95\%. In this combination, temperature contributed only minimally, net radiation asserted significant contribution in January, June, July and August, while saturation vapor pressure deficit provided such contribution only in March, April and July.

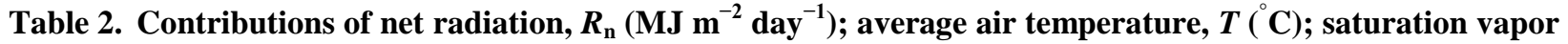
pressure deficit, $\left(e_{\mathrm{s}}-e_{\mathrm{a}}\right)(\mathrm{kPa})$, and wind speed, $u_{2}\left(\mathrm{~m} \mathrm{~s}^{-1}\right)$, to the variation of monthly average daily reference crop evapotranspiration, $E T_{0}\left(\mathrm{~mm} \mathrm{day}^{-1}\right.$ year $\left.^{-1}\right)$, in different months of the year

\begin{tabular}{|c|c|c|c|c|c|c|c|c|}
\hline \multirow[t]{2}{*}{ Month } & \multicolumn{2}{|c|}{$R_{\mathrm{n}}$} & \multicolumn{2}{|r|}{$T$} & \multicolumn{2}{|c|}{$\left(e_{\mathrm{s}}-e_{\mathrm{a}}\right)$} & \multicolumn{2}{|c|}{$u_{2}$} \\
\hline & $r^{2}$ & p-value $(\%)$ & $r^{2}$ & p-value $(\%)$ & $r^{2}$ & p-value $(\%)$ & $r^{2}$ & p-value $(\%)$ \\
\hline January & 0.6134 & 0.0001 & 0.0711 & 17.030 & 0.3840 & 0.0437 & 0.6950 & 0.000 \\
\hline February & 0.458 & 0.0076 & 0.009 & 61.990 & 0.111 & 8.3077 & 0.6370 & 0.000 \\
\hline March & 0.156 & 3.7380 & 0.068 & 17.200 & 0.522 & 0.0014 & 0.4620 & 0.006 \\
\hline April & 0.273 & 0.4290 & 0.345 & 0.101 & 0.750 & 0.0000 & 0.2703 & 0.457 \\
\hline May & 0.461 & 0.0070 & 0.207 & 1.498 & 0.545 & 0.0007 & 0.1359 & 5.356 \\
\hline June & 0.706 & 0.0000 & 0.359 & 0.075 & 0.669 & 0.0000 & 0.0123 & 57.410 \\
\hline July & 0.717 & 0.0000 & 0.535 & 0.001 & 0.763 & 0.0000 & $2.3 \mathrm{E}-06$ & 99.390 \\
\hline August & 0.704 & 0.0000 & 0.364 & 0.067 & 0.664 & 0.0000 & 0.1178 & 7.379 \\
\hline September & 0.721 & 0.0000 & 0.439 & 0.012 & 0.715 & 0.0000 & 0.0604 & 20.750 \\
\hline October & 0.313 & 0.1941 & 0.101 & 9.816 & 0.340 & 0.1112 & 0.2093 & 1.435 \\
\hline November & 0.162 & 3.3238 & 0.223 & 1.116 & 0.012 & 57.60 & 0.4646 & 0.006 \\
\hline December & 0.6220 & 0.0001 & 0.243 & 0.760 & 0.612 & 0.0001 & 0.6955 & 0.000 \\
\hline
\end{tabular}

Table 3. Combined contributions of two climatic parameters: (i) wind speed, $u_{2}\left(\mathrm{~m} \mathrm{~s}^{-1}\right)$, and net radiation, $R_{\mathrm{n}}$ $\left(\mathrm{MJ} \mathrm{m}^{-2}\right.$ day $\left.^{-1}\right)$; (ii) wind speed, $u_{2}\left(\mathrm{~m} \mathrm{~s}^{-1}\right)$ and saturation vapor pressure deficit, $\left(e_{\mathrm{s}}-e_{\mathrm{a}}\right)(\mathrm{kPa})$; and (iii) wind speed, $\mathrm{u}_{2}\left(\mathrm{~ms}^{-1}\right)$, and air temperature, $\mathrm{T}\left({ }^{\circ} \mathrm{C}\right)$, to the variation of monthly average daily reference crop evapotranspiration, $E T_{0}\left(\mathrm{~mm} \mathrm{day}^{-1}\right.$ year $\left.^{-1}\right)$, in different months of the year

\begin{tabular}{|c|c|c|c|c|c|c|c|c|c|}
\hline \multirow[t]{3}{*}{ Month } & \multicolumn{3}{|c|}{$u_{2} \& R_{\mathrm{n}}$} & \multicolumn{3}{|c|}{$u_{2} \&\left(e_{\mathrm{s}}-e_{\mathrm{a}}\right)$} & \multicolumn{3}{|c|}{$u_{2} \& T$} \\
\hline & \multirow[t]{2}{*}{$r^{2}$} & \multicolumn{2}{|c|}{ p-value (\%) } & \multirow[t]{2}{*}{$r^{2}$} & \multicolumn{2}{|c|}{ p-value (\%) } & \multirow[t]{2}{*}{$r^{2}$} & \multicolumn{2}{|c|}{ p-value $(\%)$} \\
\hline & & $u_{2}$ & $R_{\mathrm{n}}$ & & $u_{2}$ & $\left(e_{\mathrm{s}}-e_{\mathrm{a}}\right)$ & & $u_{2}$ & $T$ \\
\hline January & 0.88 & 0.000 & 0.000 & 0.95 & 0.000 & 0.000 & 0.79 & 0.000 & 0.235 \\
\hline February & 0.87 & 0.000 & 0.000 & 0.91 & 0.000 & 0.000 & 0.70 & 0.000 & 3.710 \\
\hline March & 0.72 & 0.000 & 0.007 & 0.95 & 0.000 & 0.000 & 0.55 & 0.002 & 4.580 \\
\hline April & 0.41 & 2.180 & 2.050 & 0.96 & 0.000 & 0.000 & 0.60 & 0.043 & 0.011 \\
\hline May & 0.55 & 3.560 & 0.006 & 0.89 & 0.000 & 0.000 & 0.51 & 0.054 & 0.018 \\
\hline June & 0.72 & 39.050 & 0.000 & 0.91 & 0.000 & 0.000 & 0.63 & 0.021 & 0.000 \\
\hline July & 0.72 & 85.20 & 0.000 & 0.92 & 0.000 & 0.000 & 0.79 & 0.001 & 0.000 \\
\hline August & 0.77 & 1.410 & 0.000 & 0.91 & 0.000 & 0.000 & 0.70 & 0.001 & 0.000 \\
\hline September & 0.81 & 0.200 & 0.000 & 0.93 & 0.000 & 0.000 & 0.80 & 0.000 & 0.000 \\
\hline
\end{tabular}


Mousumi et al.

\begin{tabular}{|c|c|c|c|c|c|c|c|c|c|}
\hline October & 0.72 & 0.000 & 0.000 & 0.84 & 0.000 & 0.000 & 0.43 & 0.077 & 0.424 \\
\hline November & 0.51 & 0.032 & 16.07 & 0.48 & 0.008 & 42.97 & 0.50 & 0.089 & 16.83 \\
\hline December & 0.92 & 0.000 & 0.000 & 0.95 & 0.000 & 0.000 & 0.79 & 0.000 & 0.267 \\
\hline
\end{tabular}

Table 4. Combined contributions of two climatic parameters: (i) net radiation, $R_{\mathrm{n}}\left(\mathrm{MJ}^{-2} \mathrm{day}^{-1}\right)$, and saturation vapor pressure deficit, $\left(e_{\mathrm{s}}-e_{\mathrm{a}}\right)(\mathrm{kPa})$; (ii) net radiation, $R_{\mathrm{n}}\left(\mathrm{MJ} \mathrm{m}^{-2} \mathrm{day}^{-1}\right)$, and air temperature, $T(\mathrm{C})$; and (iii) saturation vapor pressure deficit, $\left(\mathrm{e}_{\mathrm{s}}-\mathrm{e}_{\mathrm{a}}\right)(\mathrm{kPa})$, and air temperature, $T(C)$, to the variation of monthly average daily reference crop evapotranspiration, $\mathbf{E T}_{0}\left(\mathrm{~mm} \mathrm{day}^{-1}\right.$ year $^{-1}$, in different months of the year

\begin{tabular}{|c|c|c|c|c|c|c|c|c|c|}
\hline \multirow[t]{3}{*}{ Month } & \multicolumn{3}{|c|}{$R_{\mathrm{n}} \&\left(e_{\mathrm{s}}-e_{\mathrm{a}}\right)$} & \multicolumn{3}{|c|}{$R_{\mathrm{n}} \& T$} & \multicolumn{3}{|c|}{$\left(e_{\mathrm{s}}-e_{\mathrm{a}}\right) \& T$} \\
\hline & \multirow[t]{2}{*}{$r^{2}$} & \multicolumn{2}{|c|}{$\mathrm{p}$-value $(\%)$} & \multirow[t]{2}{*}{$r^{2}$} & \multicolumn{2}{|c|}{ p-value $(\%)$} & \multirow[t]{2}{*}{$r^{2}$} & \multicolumn{2}{|c|}{ p-value $(\%)$} \\
\hline & & $R_{\mathrm{n}}$ & $\left(e_{\mathrm{s}}-e_{\mathrm{a}}\right)$ & & $R_{\mathrm{n}}$ & $T$ & & $\left(e_{\mathrm{s}}-e_{\mathrm{a}}\right)$ & $T$ \\
\hline January & 0.67 & 0.011 & 5.750 & 0.61 & 0.000 & 90.04 & 0.38 & 0.150 & 99.40 \\
\hline February & 0.46 & 0.049 & 90.200 & 0.47 & 0.010 & 58.38 & 0.12 & 9.520 & 71.40 \\
\hline March & 0.53 & 67.920 & 0.017 & 0.17 & 10.020 & 60.06 & 0.53 & 0.005 & 61.09 \\
\hline April & 0.82 & 0.000 & 0.370 & 0.45 & 0.880 & 3.768 & 0.75 & 0.000 & 65.77 \\
\hline May & 0.71 & 0.100 & 0.011 & 0.57 & 0.011 & 2.020 & 0.57 & 0.012 & 27.72 \\
\hline June & 0.83 & 0.006 & 0.029 & 0.74 & 0.000 & 6.570 & 0.69 & 0.003 & 21.83 \\
\hline July & 0.91 & 0.000 & 0.000 & 0.79 & 0.001 & 0.583 & 0.78 & 0.002 & 17.99 \\
\hline August & 0.83 & 0.003 & 0.018 & 0.75 & 0.000 & 4.760 & 0.68 & 0.003 & 22.09 \\
\hline September & 0.81 & 0.218 & 0.298 & 0.74 & 0.001 & 19.140 & 0.78 & 0.000 & 1.328 \\
\hline October & 0.38 & 21.14 & 11.050 & 0.35 & 0.509 & 26.400 & 0.34 & 0.589 & 99.21 \\
\hline November & 0.17 & 3.723 & 59.370 & 0.30 & 12.100 & 3.960 & 0.22 & 90.78 & 1.510 \\
\hline December & 0.72 & 0.438 & 0.609 & 0.62 & 0.004 & 89.770 & 0.63 & 0.003 & 30.97 \\
\hline
\end{tabular}

Table 5. Combined contributions of three climatic parameters: (i) wind speed, $\mathbf{u}_{2}\left(\mathrm{~ms}^{-1}\right)$, net radiation, $\mathbf{R}_{n}(M J$ $\left.\mathrm{m}^{-2} \mathrm{day}^{-1}\right)$, and air temperature, $T$ ( $\mathrm{C}$ ); (ii) wind speed, $\mathrm{u}_{2}\left(\mathrm{~ms}^{-1}\right)$, net radiation, $\mathbf{R}_{\mathrm{n}}\left(\mathrm{MJ} \mathrm{\textrm {m } ^ { - 2 }} \mathrm{day}^{-1}\right)$,

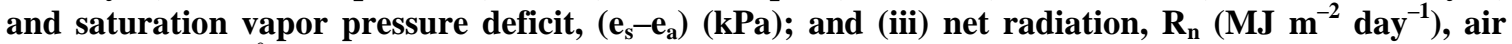
temperature, $\mathrm{T}(\mathrm{C})$, and saturation vapur pressure deficit, $\left(\mathrm{e}_{\mathrm{s}}-\mathrm{e}_{\mathrm{a}}\right)(\mathrm{kPa})$, to the variation of monthly average daily reference crop evapotranspiration, $\mathbf{E T}_{0}\left(\mathrm{~mm} \mathrm{day}^{-1}\right.$ year $\left.^{-1}\right)$, in different months of the year

\begin{tabular}{|c|c|c|c|c|c|c|c|c|c|c|c|c|}
\hline \multirow{3}{*}{ Month } & \multicolumn{4}{|c|}{$u_{2}, R_{\mathrm{n}} \& T$} & \multicolumn{4}{|c|}{$u_{2}, R_{\mathrm{n}} \&\left(e_{\mathrm{s}}-e_{\mathrm{a}}\right)$} & \multicolumn{4}{|c|}{$R_{\mathrm{n}}, T \&\left(e_{\mathrm{s}}-e_{\mathrm{a}}\right)$} \\
\hline & \multirow[t]{2}{*}{$r^{2}$} & \multicolumn{3}{|c|}{ p-value (\%) } & \multirow[t]{2}{*}{$r^{2}$} & \multicolumn{3}{|c|}{ p-value $(\%)$} & \multirow[t]{2}{*}{$r^{2}$} & \multicolumn{3}{|c|}{$\mathrm{p}$-value $(\%)$} \\
\hline & & $u_{2}$ & $R_{\mathrm{n}}$ & $T$ & & $u_{2}$ & $R_{\mathrm{n}}$ & $\left(e_{\mathrm{s}}-e_{\mathrm{a}}\right)$ & & $R_{\mathrm{n}}$ & $T$ & $\left(e_{\mathrm{s}}-e_{\mathrm{a}}\right)$ \\
\hline January & 0.90 & 0.00 & 0.01 & 5.28 & 0.98 & 0.00 & 0.00 & 0.00 & 0.67 & 0.01 & 45.69 & 4.55 \\
\hline February & 0.88 & 0.00 & 0.00 & 20.73 & 0.47 & 0.06 & 59.29 & 91.07 & 0.46 & 0.06 & 59.29 & 91.07 \\
\hline March & 0.73 & 0.00 & 0.06 & 53.43 & 0.96 & 0.00 & 4.72 & 0.00 & 0.53 & 76.64 & 67.78 & 0.03 \\
\hline April & 0.63 & 0.22 & 19.34 & 0.09 & 0.98 & 0.00 & 0.02 & 0.00 & 0.82 & 0.48 & 79.48 & 0.00 \\
\hline May & 0.77 & 0.01 & 0.00 & 0.01 & 0.96 & 0.00 & 0.00 & 0.00 & 0.71 & 0.19 & 54.31 & 0.20 \\
\hline June & 0.83 & 0.22 & 0.00 & 0.06 & 0.95 & 0.00 & 0.01 & 0.00 & 0.84 & 0.01 & 19.80 & 0.09 \\
\hline July & 0.86 & 0.18 & 0.16 & 0.00 & 0.98 & 0.00 & 0.00 & 0.00 & 0.95 & 0.00 & 0.10 & 0.00 \\
\hline August & 0.90 & 0.00 & 0.00 & 0.00 & 0.99 & 0.00 & 0.00 & 0.00 & 0.85 & 0.00 & 19.19 & 0.07 \\
\hline September & 0.93 & 0.00 & 0.00 & 0.00 & 0.97 & 0.00 & 0.00 & 0.00 & 0.84 & 0.41 & 2.40 & 0.06 \\
\hline October & 0.84 & 0.00 & 0.00 & 0.03 & 0.90 & 0.00 & 0.22 & 0.00 & 0.38 & 20.68 & 75.71 & 24.68 \\
\hline November & 0.53 & 0.19 & 24.91 & 26.13 & 0.52 & 0.04 & 17.24 & 44.90 & 0.30 & 12.99 & 5.16 & 98.13 \\
\hline December & 0.92 & 0.00 & 0.00 & 52.29 & 0.98 & 0.00 & 0.00 & 0.00 & 0.72 & 0.90 & 88.19 & 0.72 \\
\hline
\end{tabular}

\section{Conclusion}

Net radiation and wind speed decreased but air temperature and saturation vapor pressure deficit increased, all at different rates, in different months of the year during 1990 to 2017 in Mymensingh region of Bangladesh. The net radiation and wind speed played the most dominant role in the variation of reference crop evapotranspiration, $E T_{\mathrm{o}}$, over air temperature and saturation vapor pressure deficit. Consequently, the pooled effect of the climatic parameters provided a declining trend of the monthly average daily $E T_{\mathrm{o}}$ in different months of the year except July, when air temperature and saturation vapor pressure deficit exerted the most dominant role over net radiation and wind speed in $E T_{\mathrm{o}-\text { variation. The climatic parameters differed }}$ over the months of the year, and hence any fixed set of parameters did not exert similar impact on $E T_{\mathrm{o}}$ in every month of the year. If the current climatic trend continues, it is anticipated that $E T_{\mathrm{o}}$ would continue decreasing in the future in spite of the much expected increased temperature in future, as predicted by most climatic models; this anticipation is due to the lessdominant role of temperature in $E T_{\mathrm{o}}$. The decreasing trend of $E T_{\mathrm{o}}$ indicates reduced crop-water demand since it is a direct function of $E T_{\mathrm{o}}$. The trend of climatic parameters, observed during 1990-2017, if continues in the future, would therefore reduce irrigation requirement in the study area. So, the results of this study need to be considered in planning irrigation development and management based on available water resources. 


\section{References}

Abtew, W., Obeysekera, J. and Iricanin, N. 2011. Pan evaporation and potential evapotranspiration trends in south Florida. Hydrological Processes, 25(6): 958-969. https://doi.org/10.1002/hyp.7887

Adamgbe, E.M. and Ujoh, F. 2013. Effect of variability in rainfall characteristics on maize yield in Gboko, Nigeria. Journal of Environmental Protection, 4(9): 881-887. https://doi.org/10.4236/jep.2013.49103

Allen, R.G., Pereira, L.S., Raes, D. and Smith, M. 1998. Crop evapotranspiration - guidelines for computing crop water requirements. FAO Irrigation and Drainage Paper 56, Food and Agriculture Organization, Rome.

Darshana, A., Pandey, R. and Pandey, P. 2012. Analysing trends in reference evapotranspiration and weather variables in the Tons River Basin in Central India. Stochastic Environmental Research and Risk Assessment, 27(6): 1407-1421. https://doi.org/10.1007/s00477-012-0677-7

Donohue, R.J., McVicar, T.R. and Roderick, M.L. 2010. Assessing the ability of potential evaporation formulations to capture the dynamics in evaporative demand within a changing in climate. Journal of Hydrology, 386(1): 186-197. https://doi.org/10.1016/j.jhydrol.2010.03.020

Draper, N.R. and Smith, H. 2014. Applied Regression Analysis (Vol. 326). John Wiley \& Sons. New York.

Espadafor, M., Lorite, I.J., Gavilán, P. and Berengena, J. 2011. An analysis of the tendency of reference evapotranspiration estimates and other climate variables during the last 45 years in Southern Spain. Agricultural Water Management, 98(6): 1045-1061. https://doi.org/10.1016/j.agwat.2011.01.015

Gilbert, R.O. 1987. Statistical Methods for Environmental Pollution Monitoring. Van Nostrand Reinhold, New York.

Huo, Z., Dai, X., Feng, S., Kang, S. and Huang, G. 2013. Effect of climate change on reference evapotranspiration and aridity index in arid region of China. Journal of Hydrology, 492: 24-34. https://doi.org/10.1016/j.jhydrol.2013.04.011

Huq, S. and Rabbani, G. 2011. Climate change and Bangladesh: policy and institutional development to reduce vulnerability. Journal of Bangladesh Studies, 13(1): 1-10.

Irmak, S., Kabenge, I., Skaggs, K.E. and Mutiibwa, D. 2012. Trend and magnitude of changes in climate variables and reference evapotranspiration over 116-yr period in the Platte River Basin, central Nebraska-USA. Journal of Hydrology, 420: 228-244. https://doi.org/10.1016/j.jhydrol.2011.12.006

Kader, M.A., Karim, N.N. and Mojid, M.A. 2014. Impact of climate change on actual crop evapotranspiration of boro rice in Rajshahi division. Journal of Agricultural Engineering, 41/AE(2): $23-30$

Karim, N.N., Talukder, M.S.U., Hassan, A.A. and Khair, M.A. 2008. Temporal trend of reference crop evapotranspiration due to changes of climate in north-central hydrological region of Bangladesh. Journal of Agricultural Engineering, 34/AE: 91-100.

Kendall, M.G. 1975. Rank Correlation Measures. Charles Griffin: London, UK, Volume 202.

Kousari, M.R. and Ahani, H. 2012. An investigation on reference crop evapotranspiration trend from 1975 to 2005 in Iran International Journal of Climatology, 32(15): 2387-2402. https://doi.org/10.1002/joc.3404

Liu, Q., Yang, Z., Cui, B. and Sun, T. 2010. The temporal trends of reference evapotranspiration and its sensitivity to key meteorological variables in the Yellow River Basin, China. Hydrological Processes, 24(15): 2171-2181.

https://doi.org/10.1002/hyp.7649
Ma, X., Zhang, M., Li, Y., Wang, S., Ma, Q. and Liu, W. 2012 Decreasing potential evapotranspiration in the Huanghe River Watershed in climate warming during 1960-2010. Journal of Geographical Sciences, 22(6): 977-988. https://doi.org/10.1007/s11442-012-0977-3

Mann, H.B. 1945. Nonparametric tests against trend. Journal of the Econometric Society, 13: 245-259. https://doi.org/10.2307/1907187

Mojid, M.A., Rannu, R.P. and Karim, N.N. 2015. Climate change impacts on reference crop evapotranspiration in northwest hydrological region of Bangladesh. International Journal of Climatology, 35: 4041-4046. https://doi.org/10.1002/joc.4260

Ochieng, J., Kirimi, L. and Mathenge, M. 2016. Effects of climate variability and change on agricultural production: The case of small scale farmers in Kenya. NJAS-Wageningen Journal of Life Sciences, 77: 71-78. https://doi.org/10.1016/j.njas.2016.03.005

Paltineanu, C., Chitu, E. and Mateescu, E. 2012. New trends for reference evapotranspiration and climatic water deficit. International Agrophysics, 26: 159-165. https://doi.org/10.2478/v10247-012-0023-9

Papaioannou, G., Kitsara, G. and Athanasatos, S. 2011. Impact of global dimming and brightening on reference evapotranspiration in Greece. Journal of Geophysical Research: Atmospheres, 116(D09107). https://doi.org/10.1029/2010JD015525

Pouliotte, J., Smit, B. and Westerhoff, L. 2009. Adaptation and development: livelihoods and climate change in Subarnabad, Bangladesh. Climate and Development, 1(1): 31-46. https://doi.org/10.3763/cdev.2009.0001

Rannu, R.P., Karim, N.N. and Mojid, M.A. 2013. Trend of reference crop evapotranspiration under changing climate in northwest hydrological region of Bangladesh. Bangladesh Journal of Agricultural Engineering, 24(1\&2): 31-36.

Salmi, T., Maatta, A., Anttila, P., Airola, T.R. and Annell, T. 2002. Detecting trends of annual values of atmospheric pollutants by the Mann-Kendall test and Sen's slope estimates - the Excel template application Makesens. Finnish Meteorological Institute, Helsinki, Finland, p 35.

Tabari, H., Nikbakht, J. and Talaee, P.H. 2012. Identification of trend in reference evapotranspiration series with serial dependence in Iran. Water Resources Management, 26(8): 2219-2232. https://doi.org/10.1007/s11269-012-0011-7

Trenberth, K.E. and Fasullo, J.T. 2009. Global warming due to increasing absorbed solar radiation. Geophysical Research Letters, 36, L07706. https://doi.org/10.1029/2009GL037527

Vergni, L. and Todisco, F. 2011. Spatio-temporal variability of precipitation, temperature and agricultural drought indices in Central Italy. Agricultural and Forest Meteorology, 151(3): 301-313. https://doi.org/10.1016/j.agrformet.2010.11.005

Weller, G. and Wendler, G. 1990. Energy budgets over various types of terrain in polar regions. Annals of Glaciology, 14: 311314. https://doi.org/10.1017/S0260305500008818

Xu, C.Y., Gong, L., Jiang, T., Chen, D. and Singh, V.P. 2006. Analysis of spatial distribution and temporal trend of reference evapotranspiration and pan evaporation in Changjiang (Yangtze River) catchment. Journal of Hydrology, 327(12): 81-93. https://doi.org/10.1016/j.jhydrol.2005.11.029

Zhao, L., Xia, J., Sobkowiak, L. and Li, Z. 2014. Climatic characteristics of reference evapotranspiration in the Hai River basin and their attribution. Water, 6(6): 1482-1499. https://doi.org/10.3390/w6061482 